\title{
Anti-equine arteritis virus activity of ethanolic extract and compounds from Origanum vulgare
}

\section{Atividade do extrato etanólico e compostos de Origanum vulgare contra o virus da arterite equina}

\author{
Daiane Einhardt Blank ${ }^{1}$; Rayra Almeida Corrêa ${ }^{2}$; Rogério Antônio Freitag³; \\ Marlete Brum Cleff ${ }^{4}$; Silvia de Oliveira Hübner ${ }^{5 *}$
}

\begin{abstract}
The equine arteritis virus (EAV) is responsible by an important respiratory and reproductive disease in equine populations and there is no specific antiviral treatment available. The objective of this study was to investigate the activity of an ethanolic crude extract of Origanum vulgare (EEO) and of isolated compound caffeic acid, p-coumaric acid, rosmarinic acid, quercetin, luteolin, carnosol, carnosic acid, kaempferol and apigenin against EAV. The assays were performed using non-cytotoxic concentrations. The antiviral activity was monitored initially by cytopathic effect inhibition (CPE) assay in RK13 cells in the presence or absence of EEO. Pre-incubated cells with EEO were also examined to show prophylactic effect. Direct viral inactivation by EEO and isolated compounds was evaluated by incubation at $37^{\circ} \mathrm{C}$ or $20^{\circ} \mathrm{C}$. After the incubation period, the infectivity was immediately determined by virus titrations on cell cultures and expressed as $50 \%$ tissue culture infective dose $\left(\mathrm{TCID}_{50}\right) / 100 \mu \mathrm{L}$. There was significant virucidal activity of EEO and of the compounds caffeic acid, p-coumaric acid, quercetin, carnosic acid and kaempferol. When EEO was added after infection, EEO inhibited the virus growth in infected cells, as evidenced by significant reduction of the viral titre. The results provide evidence that the EEO exhibit an inhibitory effect anti-EAV. Among the main compounds evaluated, caffeic acid, p-coumaric acid, carnosic acid, kaempferol and mainly quercetin, contributed to the activity of EEO. EEO may represent a good prototype for the development of a new antiviral agent, presenting promising for combating arteriviruses infections.
\end{abstract}

Key words: Antimicrobial. Antiviral. Cytotoxicity. Origanum sp. Virucidal.

\section{Resumo}

O virus da arterite equine (EAV) é responsável por uma importante doença respiratória e reprodutiva na população de equinos e não há tratamento antiviral específico disponível. O objetivo desse estudo foi investigar a atividade de um extrato etanólico de Origanum vulgare (EEO) e dos compostos isolados ácido caféico, ácido p-cumarico, ácido rosmarínico, quercetina, luteolina, carnosol, ácido carnósico, campferol e apigenina contra o EAV. Os ensaios foram realizados com concentrações não citotóxicas. A atividade antiviral foi monitorada inicialmente por um ensaio de inibição de efeito citopático (CPE) em células RK13 na presença ou ausência do EEO. Células pré-incubadas com o EEO foram também

\footnotetext{
${ }^{1}$ Discente, Programa de Pós-Graduação em Bioquímica e Bioprospecção, Universidade Federal de Pelotas, UFPel, RS, Brasil. E-mail: daiane_blank@yahoo.com.br

2 Discente, Programa de Pós-Graduação em Ciências Veterinárias, Universidade Federal do Rio Grande do Sul, UFRGS, RS, Brasil. E-mail: rayraalmeida@gmail.com

3 Prof., Departamento de Química Orgânica, UFPel, RS, Brasil. E-mail: rafreitag@gmail.com

4 Prof., Departamento de Clínica Veterinária, UFPel, RS, Brasil. E-mail: marletecleff@gmail.com

${ }^{5}$ Prof ${ }^{\text {a }}$, Departamento de Veterinária Preventiva, UFPel, RS, Brasil. E-mail: sohubner@yahoo.com.br

* Author for correspondence
} 
examinadas para a presença de efeito profilático. Inativação direta do EAV pelo EEO e pelos compostos isolados foi avaliada mediante incubação a $37^{\circ} \mathrm{C}$ ou $20^{\circ} \mathrm{C}$. Após o período de incubação, a infectividade foi imediatamente determinada por titulação viral em cultivo celular sendo expresso como dose infectiva a $50 \%\left(\mathrm{TCID}_{50}\right) / 100 \mu \mathrm{L}$. Houve significativa atividade virucida do EEO e dos compostos ácido caféico, ácido p-cumarico, quercetina, ácido carnósico e campferol. Quando o EEO foi adicionado após a infecção, o EEO inibiu a replicação do vírus nas células infectadas, o que foi evidenciado pela redução significativa do título viral. Os resultados fornecem evidências de que o EEO possui efeito anti-EAV. Entre os principais compostos presentes avaliados, ácido caféico, ácido p-cumarico, ácido carnósico, campferol e, principalmente, quercetina, contribuíram para a atividade antiviral do extrato. O EEO pode representar um bom protótipo para o desenvolvimento de um novo agente antiviral, sendo promissor para combater infecções por arterivírus.

Palavras-chave: Antimicrobiano. Antiviral. Citotoxicidade. Origanum sp. Virucida.

\section{Introduction}

The equine arteritis virus (EAV) is the prototype of the family Arteriviridae, which also includes lactate dehydrogenase-elevating virus, porcine reproductive and respiratory syndrome virus (PRRSV), and simian hemorrhagic fever virus. EAV is an enveloped RNA virus, $35 \mathrm{~nm}$ in diameter, icosahedral nucleocapsid and with replication in the perinuclear cytoplasm of their host cells (DEL PIERO, 2000). It is responsible by equine viral arteritis (EVA), an important respiratory and reproductive disease that affects horses throughout the world (DEL PIERO, 2000; PRONOST et al., 2010). Typical cases are characterized by fever, depression, anorexia, leukopenia, and edema (especially of the lower hind extremities, scrotum, and prepuce in the stallion). Infection of pregnant mares frequently results in abortion, and the virus has occasionally been associated with foal death (PRONOST et al., 2010). EAV can establish a persistent infection in the genital tracts of peripubertal colts and stallions, besides to economic losses due to restrictions in importing and exporting of horses and semen (RUIZ-SAENZ, 2010). There is no specific antiviral treatment currently available for EVA. Thus, identifying novel antiviral drugs is of critical importance and natural products are an excellent source for such discoveries.

Origanum vulgare (Lamiaceae) is a perennial herb distributed in Europe, North Africa, America and Asia with a broad range of biological effects.
Extracts and essential oils of Origanum vulgare have been recently investigated with the interest in discovering substances with potential antiviral activity (VIMALANATHAN; HUDSON, 2012; HERNÁNDEZ et al., 2014; PENSEL et al., 2014; ZHANG et al., 2014) although no previous study has explored the activity against arteriviruses infections. In this work, we report the activity of ethanolic crude extract of Origanum vulgare and their main compounds (caffeic acid, p-coumaric acid, rosmarinic acid, quercetin, luteolin, carnosol, carnosic acid, kaempferol and apigenin) against EAV.

\section{Materials and Methods}

\section{Plant extract and compounds}

Dried leaves of Origanum vulgare (Luar Sul Indústria e Comércio de Produtos Alimentícios), lot $001 / 2011$, were immersed in $99 \%$ ethanol $(35 \mathrm{~g} / 350$ $\mathrm{mL}$ ) and maintained under constant stirring at temperature between $65^{\circ} \mathrm{C}$ to $70^{\circ} \mathrm{C}$ for 24 hours. After filtration, evaporation was performed in a rotary evaporator to obtain the extract. The dried extract and the compounds were reconstituted in dimethylsulfoxide (DMSO) and further diluted in cellular medium for determination of cytotoxicity and anti-EAV activity. The compounds caffeic acid, p-coumaric acid, rosmarinic acid, quercetin, luteolin, carnosol, carnosic acid, kaempferol and apigenin used in the study were acquired from Sigma-Aldrich ${ }^{\circledR}$. 
Identification of chemical constituents from the EEO

The EEO was analyzed by high performance liquid chromatography (HPLC) (C18 reverse phase Gemini column /Phenomenex Inc; flow rate, $1 \mathrm{~mL} /$ min; injection volume, $10 \mu \mathrm{L}$ ). The solutions of ethanolic extracts were solubilized in methanol.

\section{Cell line and virus}

RK13 cells were grown in Eagle's Medium (EMEM) (Sigma-Aldrich $\left.{ }^{\circledR}\right)$, supplemented with $10 \%$ fetal bovine serum $\left(\right.$ Gibco $\left.^{\circledR}\right)$, and antibiotics. Cells were incubated at $37^{\circ} \mathrm{C}$ in an atmosphere of $5 \% \mathrm{CO}_{2}$ incubator. The EAV Bucyrus strain propagated in RK13 cell cultures was used for all experiments.

\section{Cytotoxicity assay}

The RK13 cells were grown to $90-100 \%$ confluence. The EMEM was removed and were added different concentrations of EEO or isolated compounds (from $100 \mu \mathrm{g} / \mathrm{mL}$ to 0,1 $\mu \mathrm{g} / \mathrm{mL})$. After 48 hours cell cytotoxicity was measured by MTT (3-(4,5-dimethylthiazol-2-yl)2,5-diphenyltetrazoliumbromide) procedure as described (MOSMANN, 1983).

\section{Antiviral assays}

The inhibitory effect on EAV was investigated by virus titration. Initially antiviral activity was evaluated after EAV cellular infection, using assay described (LUGANINI et al., 2010) with some modifications. RK13 cells were infected with 100 TCID $_{50}$ by 1 hour at $37^{\circ} \mathrm{C}$, after that the residual inoculum was removed and replaced by EMEM or EMEM containing EEO at a concentration non cytotoxic $(12.5 \mu \mathrm{g} / \mathrm{mL})$. After 72 hours the microplates were frozen/thawed and viral suspensions were titrated. The virus titers were calculated using the statistical method Behrends \& Kärber and expressed as 50\% tissue culture infective dose $\left(\mathrm{TCID}_{50}\right)$.
Pre-incubated cells with EEO were also examined to show the prophylactic effect to EEO. RK 13 cells were treated 2 hours prior to infection with $12.5 \mu \mathrm{g} / \mathrm{mL}$ EEO or MOCK treated at $37^{\circ} \mathrm{C}$ and $5 \% \mathrm{CO} 2$. After, EEO was aspirated, cells were washed and on treated cells were performed EAV titrations, as described above.

\section{Viral inactivation assay}

The direct effect of EEO on EAV infectivity was evaluated by incubation with the EAV at a $37^{\circ} \mathrm{C}$ or $20^{\circ} \mathrm{C}$ by 3 or 6 hours. Viral inactivation of the isolated compounds caffeic acid, p-coumarico acid, rosmarinic acid, quercetin, carnosic acid, kaempferol and apigenin were evaluated by incubation at $20^{\circ} \mathrm{C}$ by 6 hours (all using non cytotoxic concentrations). Luteolin and carnosol did not were evaluated. The same volume of the viral inoculum without the compounds was used as control. The presence of residual infectious virus was evaluated by titration on confluent RK13 cells immediately after the incubation.

\section{Statistical analysis}

Data are presented as mean of three independent experiments. The data were submitted to analysis of variance and means were compared by Tukey test using the statistical program $\mathrm{SAS}^{\circledR}$ software. A P value $<0.05$ was considered to be statistically significant.

\section{Results and Discussion}

The chemical constituents in EEO identified by HPLC and their retention times are presented in Table 1. The compound with higher concentration was kaempferol (238 $\mathrm{mg} / \mathrm{g})$ and with lower concentration was p-coumaric acid ( $11 \mathrm{mg} / \mathrm{g})$. Rutin, vanillic acid and ferulic acid were used as standards in this study, but were not found. Such compounds have been described in the methanol extract of the plant (PROESTOS; KAPSOKEFALOU; KOMAITIS, 2008). 
Table 1. Chemical composition of ethanolic extract of Origanum vulgare by HPLC method and retention times.

\begin{tabular}{lccc}
\hline Compounds & $\begin{array}{c}\text { Standards } \\
(\boldsymbol{\mu g} / \mathbf{m L})\end{array}$ & $\begin{array}{c}\text { Retention } \\
(\mathbf{T}: \mathbf{m i n})\end{array}$ & $\begin{array}{c}\text { CCE } \\
(\mathbf{m g} / \mathbf{g})\end{array}$ \\
\hline Caffeic acid & 980 & 14,864 & 38 \\
p-coumaric acid & 980 & 25,480 & 11 \\
Rosmarinic acid & 1176 & 53,922 & 146 \\
Quercetin & 1078 & 60,328 & 81 \\
Luteolin & 980 & 60,683 & 36 \\
Carnosol & 1078 & 67,013 & 31 \\
Carnosic acid & 970 & 67,307 & 138 \\
Kaempferol & 810 & 68,080 & 238 \\
Apigenin & 1425 & 69,121 & 51 \\
\hline
\end{tabular}

CCE $(\mathrm{mg} / \mathrm{g})=$ Concentration of compound in the extract.

The EEO was not toxic to RK13 cells from 12.5 $\mu \mathrm{g} / \mathrm{mL}$. This concentration was used in all tests with the extract. The compounds tested individually showed different cytotoxicities: caffeic acid (6.6 $\mu \mathrm{g} / \mathrm{mL})$, p-coumarico acid $(31 \mu \mathrm{g} / \mathrm{mL})$, rosmarinic acid $(7.8 \mu \mathrm{g} / \mathrm{mL})$, quercetin $(13 \mu \mathrm{g} / \mathrm{mL})$, carnosic acid $(0.66 \mu \mathrm{g} / \mathrm{mL})$, kaempferol $(0.5 \mu \mathrm{g} / \mathrm{mL})$ and apigenin $(1.25 \mu \mathrm{g} / \mathrm{mL})$. Subsequent studies with these compounds were performed with treatment at these concentrations.

The EEO added on RK13 cells at 2 prior to virus infection, and then being removed by PBS washes before the infection, did not have any antiviral activity. This indicate that EEO do not induce antiviral state on RK13 cells and the compounds found in the extract did not have any direct effect on the cells, did not occupied specific receptors on the cell surface used to adsorption and or penetration of the virus particle to the cell. In the antiviral assay, when the EEO was added after virus adsorption, there was reduction significant on viral particle production, as evidenced by reduction EAV titer $(\mathrm{P}<0.01)$. In the absence of the extract the EAV showed a median titer of $10^{6.08} \operatorname{TCID}_{50} / 100 \mu \mathrm{L}$ while in the EEO presence the titer was reduced to $10^{1.75} \mathrm{TCID}_{50} / 100 \mu \mathrm{L}$ (date not show). In addition, the protocol to search viral inactivation was able to demonstrate strong action of EEO, since after 3 hours of incubation at $37^{\circ} \mathrm{C}$ or $20^{\circ} \mathrm{C}$ the viral titer were reduced from $10^{6.08}$ to $10^{3} \mathrm{TCID}_{50} / 100 \mu \mathrm{L}$ (median). After 6 hours of incubation the reduction was even more significant, from $10^{6.08}$ to $10^{1.25} \mathrm{TCID}_{50} / 100$ $\mu \mathrm{L}$ (Figure 1). As virucidal activity was detected, it was investigate what compound or compounds are responsible by this effect. Various compounds had ability to inactivate EAV when performed statistical analysis: caffeic acid, p-coumaric acid, carnosic acid, quercetin, and kaempferol (Figure 1). Of these, quercetin was the most prominent, as incubation reduce virus titer to $10^{0.6} \mathrm{TCID}_{50} / 100 \mu \mathrm{L}$.

The results show that the virucidal activity of the EEO is related to several chemical compounds. These compounds probably interact with molecules on the viral surface, preventing the adsorption and penetration into cells or making possible the disintegration of the EAV. Perhaps the reduction of virus yield using the cytopathic effect inhibition assay in RK13 also is due to inactivation of viral particles during morphogenesis or budding steps of the viral cycle. However, another mechanism of action may be existing since the quercetin, for example, known to be inhibitors of HIV-reverse transcriptase (WANG et al., 1994) and have been shown to be inhibitory to the activities of various cellular DNA and RNA polymerases (ONO; NAKANE, 1990; COTIN et al., 2012). Also it can be assumed that part of the antiviral activity of EEO relies on direct inactivation of the viral particles, 
thereby decreasing the infectivity of virus and, that this might also be occurring in the antiviral assay. In fact, virucidal activity might eclipse antiviral activity if tests of direct inactivation of viral particles are not performed. The antiviral activity of the flavonoids as quercetin, caffeic acid and kaempferol has been reported for others viruses, including porcine epidemic diarrhea virus, herpesvirus, human cytomegalovirus, and influenza virus (WANG et al., 1994; COTIN et al., 2012; AMOROS et al., 1992; CHOI et al., 2009; KUMAR et al., 2005; GRAVINA et al., 2011).

Figure 1. Titers $\left(\mathrm{TCID}_{50} / 100 \mu \mathrm{L}\right)$ of EAV before and after incubation for 6 hours at $20^{\circ} \mathrm{C}$ and in presence of ethanolic extract of Origanum vulgare (EEO) or isolated compounds (apigenin, rosmarinic acid, caffeic acid, p-coumaric acid, kaempferol, carnosic acid and quercetin) in non-cytotoxic concentrations.

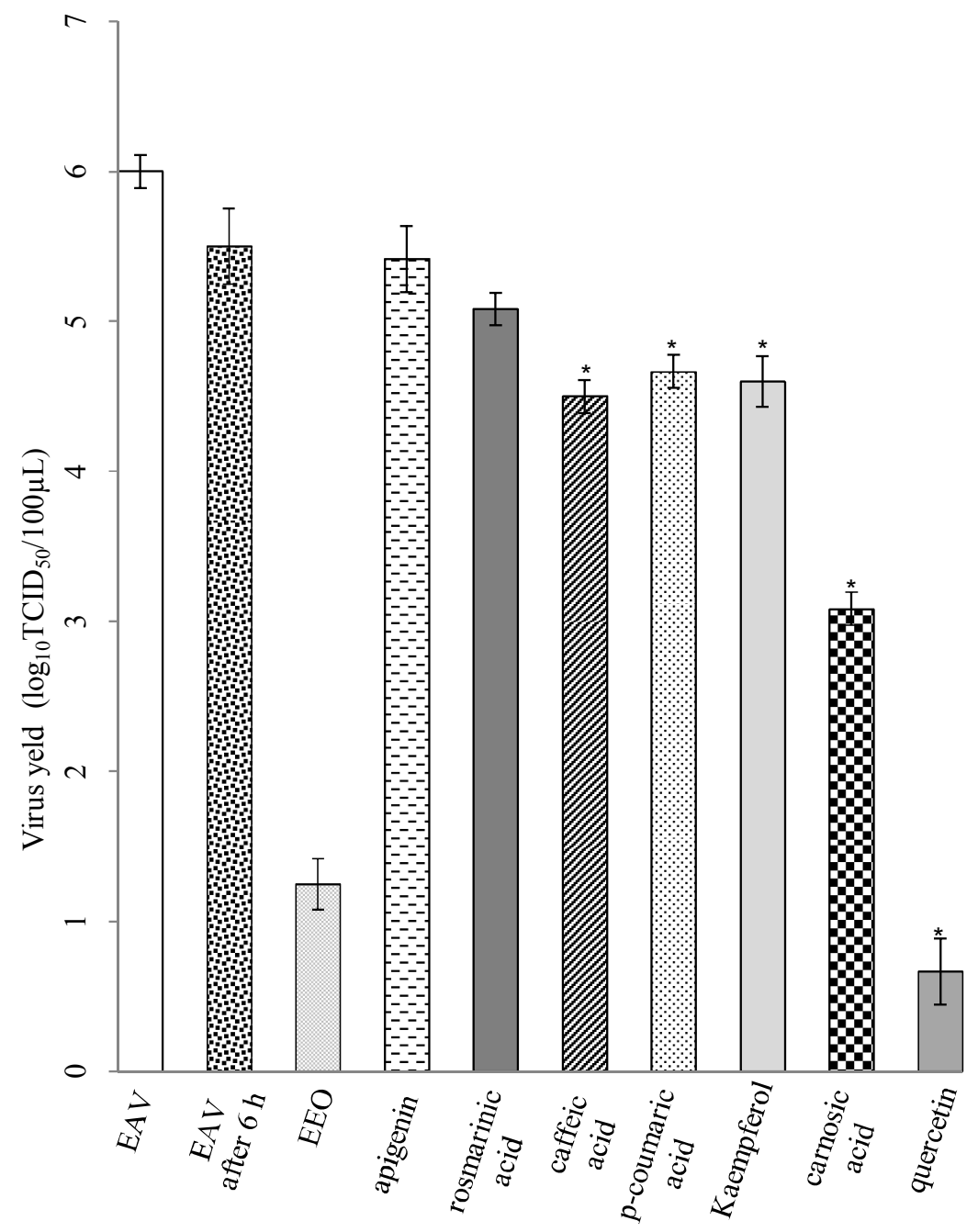

The compounds flavonoids are promising candidates as they have low toxicity and probably inhibit different targets to currently available antivirals. Our results show that the EEO and some compounds identified in Origanum vulgare have an in vitro inhibitory potential against EAV. The EEO and these compounds may provide potential inhibitors of EVA alone or in combination, with the advantage the absence of significant toxicity. EEO is virucidal and may represent a good prototype for 
the development of a new antiviral agent, presenting promising for combating arteriviruses.

\section{References}

AMOROS, M.; SIMÕES, C. M.; GIRRE, L.; SAUVAGER, F.; CORMIER, M. Synergistic effect of flavones and flavonols against herpes simplex virus type 1 in cell culture. Comparison with the antiviral activity of propolis. Journal of Natural Products, New York, v. 55, n. 12, p. 1732-1740, 1992.

CHOI, H.; KIM, J., LEE, C.; AHN, Y.; SONG, J.; BAEK, S.; KWON, D. Antiviral activity of quercetin 7-rhamnoside against porcine epidemic diarrhea virus. Antiviral Research, Victoria, v. 81, n. 1, p. 77-81, 2009.

COTIN, S.; CALLISTE, C.; MAZERON, M.; HANTZ, S.; DUROUX, J.; RAWLINSON, W.; PLOY, M.; ALAIN, S. Eight flavonoids and their potential as inhibitors of human cytomegalovirus replication. Antiviral Research, Victoria, v. 96, n. 2, p. 181-186, 2012.

DEL PIERO, F. Equine viral arteritis. Veterinary Pathology, Ontario, v. 37, n. 4, p. 287-296, 2000.

GRAVINA, H. D.; TAFURI, N. F.; SILVA JUNIOR, A.; FIETTO, J. L. R.; OLIVEIRA, T. T.; DIAZ, M. A. N.; ALMEIDA, R. In vitro assessment of the antiviral potencial of trans-cinnamic acid, quercetina and morin against equid herpesvirus 1. Research Veterinary Science, Alberta, v. 91, n. 3, p. 158-162, 2011.

HERNÁNDEZ, E. H.; GONZÁLEZ, C. R.; LANDAVERDE, P. V.; LEGARRETA, I. G.; ALMENDÁREZ, B. E. G. Microencapsulation, chemical characterization, and antimicrobial activity of Mexican (Lippia graveolens H.B.K.) and European (Origanum vulgare L.) Oregano essential oils. The Scientific World Journal, London, v. 2014, n. 1, p. 1-12, 2014.

KUMAR, P.; KHANNA, M.; SRIVASTAVA, V.; TYAGI, Y. K.; RAJ, H. G.; RAVI, K. Effect of quercetin supplementation on lung antioxidants after experimental influenza virus infection. Experimental Lung Research, Alberta, v. 31, n. 5, p. 449-459, 2005.

LUGANINI, A.; GIULIANI, A.; PIRRI, G.; PIZZUTO, L.; LANDOLFO, S.; GRIBAUDO, G. Peptidederivatized dendrimers inhibit human cytomegalovirus infection by blocking virus binding to cell surface heparan sulfate. Antiviral Research, Victoria, v. 85, n. 5, p. 532-540, 2010.
MOSMANN, T. Rapid colorimetric assay for cellular growth and survival: application to proliferation and cytotoxicity assays. Journal of Immunological Methods, Palo Alto, v. 65, n. 1-2, p. 55-63, 1983.

ONO, K.; NAKANE, H. Mechanisms of inhibition of various cellular DNA and RNA polymerases by several flavonoids. Journal of Biochemistry, Oxford, v. 108, n. 4, p. 609-613, 1990.

PENSEL, P. E.; MAGGIORE, M. A.; GENDE, L. B.; EGUARAS, M. J.; DENEGRI, M. G.; ELISSONDO, M. C. Efficacy of essential oils of Thymus vulgaris and Origanum vulgare on Echinococcus granulosus. Interdisciplinary Perspectives on Infectious Diseases, Washington, v. 2014, n. 1, p. 1-12, 2014.

PROESTOS, C.; KAPSOKEFALOU, M.; KOMAITIS, M. Analysis of naturally occurring phenolic compounds in aromatic plants by RP-HPLC and GC-MS after silylation. Journal of Food Quality, New York, v. 31, n. 3, p. 402-414, 2008.

PRONOST, S.; PITEL, P. H.; MISZCZAK, F.; LEGRAND, L.; MARCILLAUD-PITEL, C.; HAMON, M.; TAPPREST, J.; BALASURIYA, U. B. R.; FREYMUTH, F.; FORTIER, G. Description of the first recorded major occurrence of equine viral arteritis in France. Equine Veterinary Journal, Oxford, v. 42, n. 8, p. 713-720, 2010.

RUIZ-SAENZ, J. Equine viral arteritis: epidemiological and intervention perspective. Colombian Journal of Animal Science and Veterinary Medicine, Medellín, v. 23, n. 4, p. 501-512, 2010.

VIMALANATHAN, S.; HUDSON, J. Anti-Influenza virus activities of commercial Oregano oils and their carriers. Journal of Applied Pharmaceutical Science, Bangalore, v. 2, n. 7, p. 214-218, 2012.

WANG, J. N.; HOU, C. Y.; LIU, Y. L.; LIN, L. Z.; GIL, R. R.; CORDELL, G. A. Swertifrancheside, an HIV-reverse transcriptase inhibitor and the first flavone-xanthone dimmer, from Swertia franchetiana. Journal Natural Products, New York, v. 57, n. 2, p. 211-217, 1994.

ZHANG, X. L.; GUO, Y. S.; WANG, C. H.; LI, G. Q.; XU, J. J.; CHUNG, H. Y.; YE, W. C.; LI, Y. L.; WANG, G. C. Phenolic compounds from Origanum vulgare and their antioxidant and antiviral activities. Food Chemistry, Amsterdam, v. 152, n. 1, p. 300-306, 2014. 